\title{
Application of deltamethrin for spraying or dipping to protect Scots pine seedlings against Hylobius abietis $L$ and logs against Tomicus piniperda $\mathrm{L}$
}

\author{
B Glowacka*, A Lech, W Wilczynski \\ Forest Research Institute, Wery-Kostrzewy 2, 00-973 Warsaw, Box 61, Poland
}

(Received 9 January 1990; accepted 28 September 1990)

\begin{abstract}
Summary - The authors compared the efficiency of protecting Scots pine trees against Hylobius abietis $\mathrm{L}$, the large pine weevil, using deltamethrin (Decis 2.5 EC) by dipping seedlings before planting and by spraying after planting. Assessment of damage caused by the beetles and the rate of degradation of the insecticide on the plants proved that dipped seedlings were less frequently damaged and were protected by 10 times the quantity of active insecticide ingredient than sprayed plants. Experiments were also carried out to analyse the application of deltamethrin in the protection of wood before bark stripping against Tomicus piniperda $L$, the pine-shoot beetle. Treatments were carried out after the last frosts in the early spring and during the first days of swarming. Analysis of infested wood and the degradation of the deltamethrin in the bark showed a high degree of insecticide persistence and thus the possibility of efficient protective treatment 2-3 wk before the swarming period.
\end{abstract}

Hylobius abietis / Tomicus piniperda / Pinus sylvestris / deltamethrin

Résumé - Application de deltaméthrine pour la protection des jeunes pins sylvestres contre l'hylobe du pin, Hylobius abietis $\mathrm{L}$ et celle des bois coupés contre l'hylesine du pin, Tomicus piniperda L. On a comparé l'efficacité de la deltaméthrine sur des plants de pin sylvestre contre l'hylobe, Hylobius abietis L. La deltaméthrine, Decis 2.5 EC a été appliquée par trempage des plants avant la plantation ou pulvérisée en forêt après la plantation. On a ensuite évalué les dégâts causés par les adultes et la dégradation dans le temps de l'insecticide sur les plants. Les plants trempés dans la solution de deltaméthrine à $0,025 \%$ étaient moins fréquemment endommagés et contenaient 10 fois plus de matière active insecticide que les plants pulvérisés. Des essais d'application de deltaméthrine ont aussi été réalisés pour protéger le bois de pin non écorcé contre l'hylesine du pin, Tomicus piniperda $L$. Le traitement était fait au début du printemps après les gelées et au début de la période d'essaimage des insectes. Le nombre d'insectes trouvés sur le bois pulvérisé et la quantité de deltaméthrine retrouvée dans l'écorce prouvent une grande persistance de l'insecticide et la possibilité de traiter le bois efficacement 2-3 semaines avant la période d'essaimage.

hylobius abietis / Tomicus piniperda / Pinus sylvestris / deltamethrine

\footnotetext{
* Correspondence and reprints
} 


\section{INTRODUCTION}

Decis 2.5 EC is mainly used in Poland for forest protection against leaf eating larvae, bark beetles and large pine weevils. In 1983, during the Lymantria monacha $L$ nun moth outbreak, $78.2 \mathrm{t}$ of Decis were applied. $18.727 .7,9.3$ and $13.1 \mathrm{t}$ of the product were used respectively during the 1984-1987 period. The exact quantity of Decis used in 1988 is not yet known but will probably be high due to outbreaks of the Panolis flammea Schiff pine beauty moth and the Bupalus piniarius $\mathrm{L}$ pine looper which required the product to be used over 180000 and 30000 ha respectively.

Deltamethrin is used at doses of 2.5-6 $\mathrm{g}$ of active ingredient per ha in the control of leaf eating larvae, especially species belonging to the Lepidoptera and Hymenoptera families. At higher doses it is used in the protection of wood against the bark beetle and the control of the pine weevil in pine plantations.

\section{EXPERIMENT WITH T PINIPERDA}

Wood is generally protected from Tomicus piniperda $\mathrm{L}$, the larger pine shoot beetle, Ips typographus, the spruce bark beetle and Trypodendron lineatum $\mathrm{L}$, the ambrosia beetle. The wood is treated by spraying the logs (before the bark is stripped) with a Decis emulsion (Koehler et al, 1972); the treatment should be carried out at the beginning of the insect swarming period. It is difficult to treat the wood at this time as the beginning of the spring swarming period is not easy to predict and there are practical difficulties in organising spraying. Infestation often occurs where great quantities of wood require treatment because the bark cannot be stripped or re- moved from the forest quickly enough and where the treatment capacities of the local forestry commission are limited.

We carried out a number of experiments in the Forest Protection Department of the Warsaw Forest Research Institute in 1986 and 1987. These concerned improvements to insecticide application methods for use in Scots pine wood protection. We compared the efficiency of treatments using Decis over 2 spring periods.

In 1986, experiments were carried out in the Sekocin Forest Research Institute examining the extent of beettle attack on pinewood treated with Decis. At the beginning of March, round shaped pine logs from the winter cutting season were stacked in groups and sprayed on 2 different dates. Some of the wood was sprayed on 10 March immediately after the last frost (2-3 wk before the beginning of the insect swarming period) and the remaining wood was sprayed 3 wk later on 1st April during the first days of swarming. A number of logs were left unsprayed as controls.

In 1987, experiments were carried out in the Lochow district timber yards. We sprayed 2 stacks, each containing 10 pine logs, on 24 March and during the insect swarming period on 14 April.

The final inspection of wood infestation was carried out 3 months later. This consisted of taking a 1-m length section of wood cut through the middle of each log, removing the bark and counting the number of living and dead insects in the larval galleries. The degradation rate of deltamethrin in the sprayed bark was then evaluated.

In each experiment, we took samples of the sprayed bark and, using gas chromatography, evaluated the deltamethrin content and its degradation rate. The bark was weighed, its surface area measured and, after grinding, the remaining insecticide 
was extracted. On the basis of the results obtained, and having accounted for the weight and surface area of each sample, we calculated the deltamethrin content per $1 \mathrm{~m}^{2}$ using the following formula:

$$
y=\frac{a c}{10 b}
$$

in which: $y=$ deltamethrin content expressed in $\mathrm{g} / \mathrm{m}^{2}$ of bark; $a=$ weight of sample in $\mathrm{g} ; b=$ surface area of sample in $\mathrm{dcm}^{2} ; c=$ deltamethrin content expressed in $\mathrm{mg} / \mathrm{kg}$ of bark.

The results of the analysis determining the beetle infestation of pine logs demonstrated that there was a distinct difference between the number of beetles in treated and untreated wood. In the 4 different experiments ( 2 in 1986 and 2 in 1987) the number of living beetles on a $1-\mathrm{m}$ long section of treated wood varied from 0.55 to 2.11 and the number of dead beetles varied from 1.82 to 8.33 .

In the 2 cases where the wood was untreated, the number of living beetles varied from 13.18 to 31.60 and the number of dead beetles varied from 0.03 to 0.35 . There was little difference between the 2 dates in the infestation rate of the treated woodpiles. In 1986, a 1-linear $m$ section of wood treated 3 weeks before the beginning of the swarming period provided 7.2 beetles, both living and dead; in the wood treated after the beginning of the swarming period we found 10.4 beetles. In 1987, the same sampling system provided 3.3 and 2.9 beetles respectively.

Analysis of the deltamethrin content in both experiments demonstrated that 32 to $37 \mathrm{mg}$ of active ingredient were deposited on a $1-\mathrm{m}^{2}$ section of bark $1 \mathrm{~h}$ after spraying and that there was a difference in the degradation rate in the first week following spraying. The deltamethrin content de- creased to approximately $60 \%$ of its initial content in 1986 and to $30-40 \%$ in 1987.

The varying influences of temperature and sunlight on the deltamethrin in the 2 experiments could explain the different rates of insecticide degradation in the first week of treatment (Carle et al, 1979; Duguet and Dartigues, 1987).

The quantity of insecticide in the bark 2 mths after spraying was similar in both experiments, ranging from 4 and $7 \mathrm{mg} / \mathrm{m}^{2}$. These values were approximately 10 times greater than the quantities of the insecticide on $1 \mathrm{~m}^{2}$ of trees sprayed from the air against leaf eaters; the deltamethrin dosage for this latter type of application ranges from 2.5 to $6 \mathrm{~g} / \mathrm{ha}$.

The results obtained demonstrated that Decis has a particularly persistent effect when sprayed on wood and thus provides high performance levels when sprayed a few weeks before the beginning of the insect swarming period. This type of early preventative treatment protects large amounts of wood.

\section{EXPERIMENTS WITH H ABIETIS}

During the past few years, the Hylobius abietis L large pine weevil has become a great problem in the protection of pine plantations in Poland. When this pest appears in numbers that threaten the plantation, the plants are sprayed with a waterbased insecticide emulsion, including Decis, in concentrations of 1 to $2 \%$ and using 100-300 I per ha. Plants are not protected by dipping before planting as forest planting work is sometimes carried out by children.

In 1987, 2 experiments were carried out in the Forest Research Institute to compare the efficiency of protection measures taken against the large pine weevil. We 
used Decis 2.5 EC for dipping seedlings before planting or for spraying after planting in the plantation. The experiments were carried out at the end of April in the Lochow and Myszyniec forest districts. We carried out the same experiment variants in both districts, these being the dipping of seedlings before planting in a 1 and $2 \%$ emulsion and the spraying of untreated planted seedlings using the same emulsion proportions.

The evaluation of treatment efficiency was carried out in both districts after 6, 10 and 16-wk periods. All plants on experimental plots were inspected and a count was made of healthy, damaged and dead plants. Plant samples were taken $1 \mathrm{~h}$ after treatment and at the end of each inspection period to ascertain the deltamethrin content.

As treatments in both forest districts were carried out under similar conditions, the results obtained were extrapolated and presented as an average result for both experimental sites. Of approximately 8400 plants, 5242 were treated and 3149 untreated. In all cases, the application of Decis by both dipping and spraying significantly increased the percentage of healthy plants and dipped plants suffered less damage than those that were sprayed. Similar results were obtained by Duguet (1985). After a 4-month period, approximately $0.4 \%$ dipped plants and $7 \%$ sprayed plants showed signs of damage, and $1 \%$ and $5 \%$ respectively were dead; whereas the number of damaged plants on untreated control plots represented $32.7 \%$ and those killed $28.1 \%$.

Gas chromatography analysis of insecticide levels in the experimental plants was carried out over the same period. This revealed that, depending on whether the plants had been sprayed or dipped, there was a considerable difference in the delta- methrin content. The results showed that $1 \mathrm{~h}$ after dipping in a $1 \%$ and $2 \%$ emulsion, there was an .18-23 $\mathrm{mg}$ and 33-41 $\mathrm{mg}$ deltamethrin content respectively in a $1-\mathrm{kg}$ plant matter sample. However, in plants sprayed at the same concentration levels, the deltamethrin content represented 1.4$1.6 \mathrm{mg} / \mathrm{kg}$ and $2.7-3.0 \mathrm{mg} / \mathrm{kg}$ respectively. Six wk after treatment, the deltamethrin content in dipped plants dropped to 0.24 $0.35 \mathrm{mg} / \mathrm{kg}$ and $0.36-0.68 \mathrm{mg} / \mathrm{kg}$ respectively and for sprayed plants dropped to $0.018-0.035 \mathrm{mg} / \mathrm{kg}$ and $0.028-0.115 \mathrm{mg} /$ $\mathrm{kg}$. After $10 \mathrm{wk}$ the deltamethrin content of plants dipped in a $1 \%$ emulsion represented $0.1-0.012 \mathrm{mg} / \mathrm{kg}$ and those dipped in a $2 \%$ emulsion represented 0.013-0.015 $\mathrm{mg} / \mathrm{kg}$. As the insecticide detection method can only measure from $0.01 \mathrm{mg} / \mathrm{kg}$ upwards, it was not possible to determine the presence of deltamethrin content after a 3wk period.

The results demonstrated that deltamethrin, applied by either dipping or spraying the seedlings, efficiently protects plantations from damage caused by the large pine weevil. The plant protection efficiency and the active ingredient content depended on the way the insecticide was applied. The results obtained demonstrated that dipped plants were damaged to a lesser degree than those that were sprayed and contained 10 times more of the active ingredients.

Ten wk after treatment, deltamethrin was detected in dipped plants in quantities greater than $0.01 \mathrm{mg} / \mathrm{kg}$, whereas the content in sprayed plants was undetectable. Taking the results obtained into account and the fact that dipping of seedlings uses less insecticide per ha (which is important economically and is vital for the environment), we can state that plantation protection from pine weevils should be carried out by dipping and that plantation spraying 
should only be carried out under exceptional conditions.

\section{REFERENCES}

Carle P, Vincq JP, Bizet M (1979) Essais de protection des bois abattus sur chantier d'exploitation par contrôle des attaques des scolytes. Forêt Privée No 217
Duguet J (1985) Essais de lutte contre l'hylobe menés en 1984 dans les plantations résineuses de Rhône-Alpes, Auvergne et Limousin. CEMAGREF, Div Prot Nature, 1-17

Duguet J, Dartigues V (1987) Efficiency of deltamethrin associated with TCMTB and MBT for temporary protection of timbers immediately following their sawing, in tropical countries. IRG/WP 18th Annual Meeting, Honey Harbour, May 1987

Koehler (1972) Instrukcja Ochrony Lasu. Pwril Warsaw , 116-188, pp 236 